\title{
pH and Temperature Dependent Gut Enzyme Niche in a Stomachless Herbivorous Freshwater Fish Amblypharyngodon mola (Hamilton, 1822)
}

\author{
S. Debnath ${ }^{1}$, S. I. Maiti ${ }^{2}$, S. K. Saikia ${ }^{1 *}$ \\ ${ }^{1}$ Department of Zoology, Visva-Bharati University, Santiniketan, West Bengal - 731235, India \\ ${ }^{2}$ Department of Statistics, Visva-Bharati University, Santiniketan, West Bengal - 731235, India
}

Received 27 March 2020, accepted in final revised form 7 June 2020

\begin{abstract}
The activities of digestive $\alpha$-amylase (E. C. 3.2.1.1), total proteases, and bile salt-activated lipase (E. C. 3.1.1.-) along the digestive tract (lengthwise divided into five equal parts) of a stomachless freshwater fish $(\mathrm{n}=10$, weight $=4.354 \pm 0.316 \mathrm{~g}$, standard length $=$ $21.641 \pm 2.271 \mathrm{~cm}$ ) were measured at different $\mathrm{pH}$ and temperature levels. Different optimum $\mathrm{pH}$ and temperature for the activity of $\alpha$-amylase $\left(8-9,35^{\circ} \mathrm{C}\right)$, proteases $\left(7-8,45^{\circ} \mathrm{C}\right)$, and lipase $\left(8,45^{\circ} \mathrm{C}\right)$ were observed. The first two regions of the digestive tract showed comparatively higher activity of all enzymes. The hierarchical clustering technique revealed three different enzymatically active regions, more inclined to $\mathrm{pH}$ in the digestive tract of the studied fish. The present study also supports that the stomachless gut of $A$. mola has substantial resemblances to the intestinal part of the digestive tract of fish.
\end{abstract}

Keywords: $\alpha$-amylase; Amblypharyngodon mola; Bile salt-activated lipase; Herbivorous fish; Proteases; Stomachless gut.

(C) 2020 JSR Publications. ISSN: 2070-0237 (Print); 2070-0245 (Online). All rights reserved. doi: http://dx.doi.org/10.3329/jsr.v12i4.46003

J. Sci. Res. 12 (4), 729-741 (2020)

\section{Introduction}

Digestion is a fundamental process in the metabolism of animals because it determines the availability of nutrients needed for all biological concerns where digestive enzymes play a key role [1]. In case of fish, Saikia [2] suggested enzyme assay from gut as a more convincing way to explain the qualitative selection of feeds in the environment. In all aquatic species including fish, digestive enzyme activity serves as a good indicator of their feeding ecology and trophic niche in natural conditions [3].

Amblypharyngodon mola (family Cichlidae) has recently received attention as a potential animal crop for alleviating malnutrition in human populations because of its capability to retain high amounts of micronutrients [4-6]. It is reported to be exceptionally rich in vitamin A, calcium and iron [7-9]. This species thrives in small freshwater bodies and is indigenous to south and south-east Asia, including India, Bangladesh, Pakistan, Myanmar, Nepal and Bhutan [10]. In IUCN databases, this fish is recorded as 'least

\footnotetext{
*Corresponding author: surjyasurjya@gmail.com
} 
concern', although unreported cases of vast loss of the habitat of this species have occurred. Several research works have been carried out on its growth, longevity [11-14], feeding [15,16] and reproductive biology [17-19]. However, the biochemical feature of the gut has not been considered while characterizing its nature of feeding. For culture practices, it is necessary to understand the behavior of the gut enzymes to biochemically classify its food and feeding environment. An attempt has, therefore, been made to understand the digestibility pattern to correlate the existing knowledge on the feeding ecology of this fish. Such knowledge of digestibility is also important for the formulation of different feeds to grow out culture of the fish. The study also aimed to examine how these enzymes are distributed along the digestive tract of the fish and whether their action follows any spatial dependent action regulated by $\mathrm{pH}$ or temperature or both.

\section{Materials and Methods}

\subsection{Experimental animals}

The fish were collected from a local fish pond, Hatserandi, Birbhum, West Bengal, India $\left(23^{\circ} 37^{\prime} \mathrm{N}, 8^{\circ} 49^{\prime} \mathrm{E}\right)$ in July 2018 using gill net during early hours (08:00-09:00 am) and brought alive to the laboratory and kept unfed for $48 \mathrm{~h}$ in fiberglass aquaria $(45 \times 30 \times 30$ $\mathrm{cm}, 30 \mathrm{~L}$ ). The temperature of the aquarium was maintained at $24.67 \pm 1.87{ }^{\circ} \mathrm{C}$; dissolved oxygen (D. O.) $7.52 \pm 0.21 \mathrm{mg} / \mathrm{L} ; \mathrm{pH} 7.47 \pm 0.32$; conductivity $616 \pm 20.9 \mu \mathrm{S}$ and photoperiod 12:12 (light hour: dark hour). The measurements of $\mathrm{pH}$, temperature and conductivity were recorded with the help of a digital multi-parameter tester (PCSTestr 35, Oakton). D. O. was measured by an oxygen meter (DO-5510, Lutron).

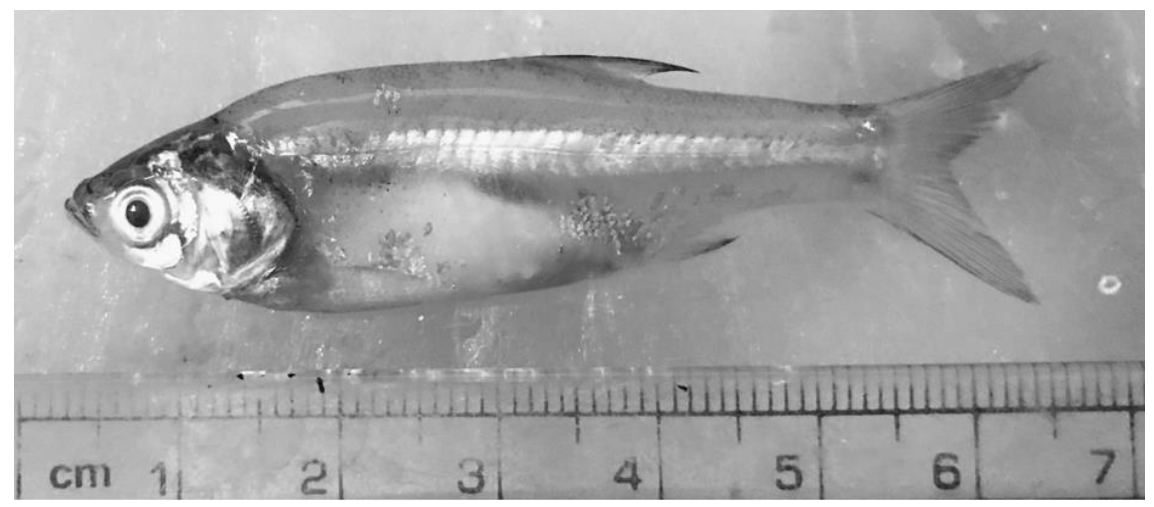

Fig. 1. Gross morphology of adult Mola (Amblypharyngodon mola).

\subsection{Chemicals}

p-nitrophenyl palmitate was purchased from Sigma, UK. Other chemicals used in this study were purchased from Sisco Research Laboratories Pvt. Ltd. (SRL), India. All chemicals used were of analytical grade. 


\subsection{Measurement of gut index}

Several gut parameters were calculated, i.e. relative gut mass $(\mathrm{RGM})=$ gut mass $(\mathrm{g}) \times$ body mass $(\mathrm{g})[20]$, relative gut length $(\mathrm{RGL})=$ gut length $(\mathrm{mm}) /$ standard length $(\mathrm{mm})$ [21] , and Zihler's Index $(\mathrm{ZI})=$ gut length $(\mathrm{mm}) / 10 \times[\text { body mass }(\mathrm{g})]^{1 / 3}[22]$.

\subsection{Preparation of extracts}

Before dissection of fish a small amount of food was introduced to stimulate the digestive system for a short time. The whole gut was removed and washed in chilled distilled water. The gut was divided into five segments of equal length and identified as Mola anterior (MA), middle 1 (MM1), middle 2 (MM2), middle 3 (MM3) and posterior (MP). Samples $(\mathrm{n}=10)$ were pooled and homogenized with a micro pestle (Tarsons) at $4{ }^{\circ} \mathrm{C}$ in $0.1 \mathrm{M}$ Tris- $\mathrm{HCl}$ buffer, $\mathrm{pH} 7.4$ then centrifuged (K2015R, UK) at $10,000 \mathrm{~g}$ at $4{ }^{\circ} \mathrm{C}$ for $10 \mathrm{~min}$, and the supernatants were collected carefully.

\subsection{Estimation of digestive enzymes}

The activity of $\alpha$-amylase (E. C. 3.2.1.1) was measured following Bernfeld [23] and the enzyme activity was expressed as the measure of $U(1 \mu \mathrm{g}$ maltose liberated per hour) per $\mu \mathrm{g}$ protein. Casein was used [24] to measure the activity of total proteases according to Walter [25]. One unit of enzyme activity in each sample was expressed as the amount of enzyme required to liberate $1 \mu \mathrm{g}$ of tyrosine in one hour. Bile salt-activated lipase (E. C. 3.1.1.-) activity was assayed according to German et al. [3] using 4-nitrophenyl palmitate as substrate and results were expressed in $\mathrm{U}(1 \mu \mathrm{g}$ 4-nitrophenol liberated per hour) per $\mu \mathrm{g}$ protein. Determination of the protein was done following Lowry et al. [26].

\subsection{Determination of optimal $\mathrm{pH}$ and temperature range}

At first, the optimal $\mathrm{pH}$ for each type of enzyme activity was determined by spectrophotometer (UV-1800, Shimadzu, Japan) using different buffer solutions ranging from $\mathrm{pH} 1$ to 10 as an assay medium with appropriate substrate solution and the homogenized extract, which was prepared from each gut region containing the active enzymes into it. The buffers used were $0.2 \mathrm{M} \mathrm{KCl}-\mathrm{HCl}$ buffer ( $\mathrm{pH} 1$ and 2), $0.2 \mathrm{M}$ glycine- $\mathrm{HCl}$ buffer ( $\mathrm{pH} 3$ ), $0.1 \mathrm{M}$ citrate buffer ( $\mathrm{pH} \mathrm{4,} \mathrm{5,} \mathrm{and} \mathrm{6),} 0.2 \mathrm{M}$ tris-HCl buffer ( $\mathrm{pH} 7,8$, and 9), $0.2 \mathrm{M}$ glycine- $\mathrm{NaOH}$ ( $\mathrm{pH} 10$ ) respectively. Particularly for lipase activity, the range of $\mathrm{pH}$ was fixed from $\mathrm{pH} 7$ to 10 , as it can be active only in neutral to the alkaline environment [27-29]. Optimal temperatures for enzymes from each gastrointestinal tract region were determined by assaying their activity at different temperatures in a standard shaking water bath (Instrumentation India) starting from 25 to $65{ }^{\circ} \mathrm{C}$ (for amylase), $60{ }^{\circ} \mathrm{C}$ (for proteases) and $50{ }^{\circ} \mathrm{C}$ (for lipase) with $5{ }^{\circ} \mathrm{C}$ interval under optimal pH until a very low value of activity was observed. The spectrophotometric activity assays were performed in triplicate and the whole work has been done thrice. 


\subsection{Data analysis}

One-way ANOVA was performed and followed by Tukey's post hoc test to elucidate the proper distribution of active digestive enzymes along the length of the gut. For two-way ANOVA, $\mathrm{pH}$ responses were divided as low to moderate $(\mathrm{pH} 1-6)$ and moderate to high (pH 5-10) for both amylase and proteases activity. Considering heavy tailed distribution of the data, Scheirer-Ray-Hare nonparametric test of two ways ANOVA was used to understand the strengths of impact of different $\mathrm{pH}$, temperature and gut regions upon the activity of different enzymes. The alpha level was taken as 0.05 for all statistical analysis. Results were reported as mean values with SE.

Furthermore, the similarity patterns of the enzyme activity among the said gut regions with the change of temperature and $\mathrm{pH}$ were studied through clustering technique on scaled variables. Here, "single linkage agglomerative clustering" was performed which merges similar objects by 'nearest neighborhood' strategy based on the Euclidean distance matrix. Additionally, for double-checking, Ward's "minimum error variance within cluster" criterion of partitioning was adapted and to verify whether a similar type of partitioning was achieved or not, the corresponding dendrograms were showcased. Subsequently, silhouette analysis was performed to check the quality of clustering, hence scrutinizing the validity of consistency within the cluster of data. All the statistical analyses were done using R Studio (version 3.5.1) and some graphs were prepared in GraphPad PRISM (version 5.01).

\section{Results and Discussion}

\subsection{Digestive tract index data}

In fish, the digestive tract is a thin long straight continuous tube with or without a stomach. Earlier, guts from stomachless fish were divided into four equal regions as proximal, middle, distal and rectal $[30,31]$. However, in the present case of A. mola it was divided into five equal regions for a precise understanding of the functional features of enzymatic activity. Calculated RGM, RGL and ZI were $2.02 \pm 0.65,3.59 \pm 0.17$ and $14.10 \pm 1.87$ respectively. The high value of $\mathrm{RGM}$, which is a relative indicator of herbivory [32] and is an attribute of the digestive tract in fish [21], suggested A. mola as an herbivore. The high RGL and ZI values also supported the similar nature of the fish $[33,34]$.

\subsection{Determination and distribution of digestive enzymes}

The enzyme, $\alpha$-amylase is the primary glucosidase found in fish [35]. Distribution of amylase activity along the intestine of $A$. mola is summarized in Fig. 2. The higher activity of amylase was associated with the proximal parts (MA, MM1) over the middle (MM2, MM3) and distal (MP) parts of the gut. Higher activity of amylase may be due to the proximal association of the hepatopancreas, but the source of moderate amylase 
activity in the distal part was unknown. A similar pattern was reported in herbivorous fish Arrhamphus sclerolepi, where higher amylase activity in the anterior part of the gut portion was followed by the subsequent parts of the intestine [30]. High amylolytic activity is coordinated with starch digestion and glucose absorption, which occur mainly in the anterior part of the intestine [36,37]. Being a herbivore fish, A. mola mainly feeds on phytoplankton [16], a good source of carbohydrate and this fact could be supplemented by the findings of this study when amylase activity was predominant over protease and lipase activity in the gut. Generally, herbivorous fish have high amylolytic activity than carnivorous fish, which have a low-carbohydrate diet [38].

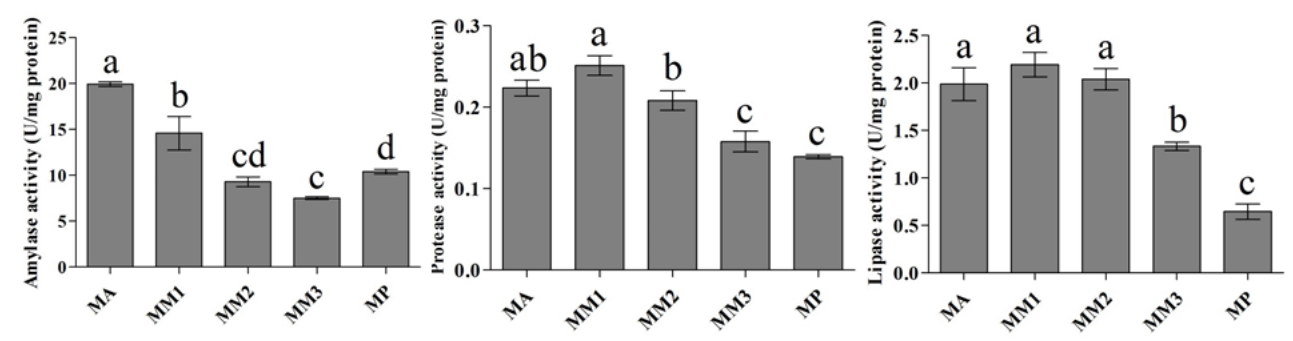

Fig. 2. Activity of amylase (left) along the digestive tract of Amblypharyngodon mola $(\mathrm{n}=10)$. Values are expressed as mean \pm SE. Bars marked with differing letters are significantly different (one-way ANOVA, $\mathrm{P}<0.05$ ).

The activities of the amylase enzyme in MA and MM1 segments had an optimum $\mathrm{pH}$ of 9 (Fig. 3.) and the other segments shared a common optimum $\mathrm{pH}$ of 8 . Optimum $\mathrm{pH}$ for the enzyme activity may vary along the digestive tract [29,39] and within different fish species $[40,41]$ as several isoforms may be present for a particular enzyme.
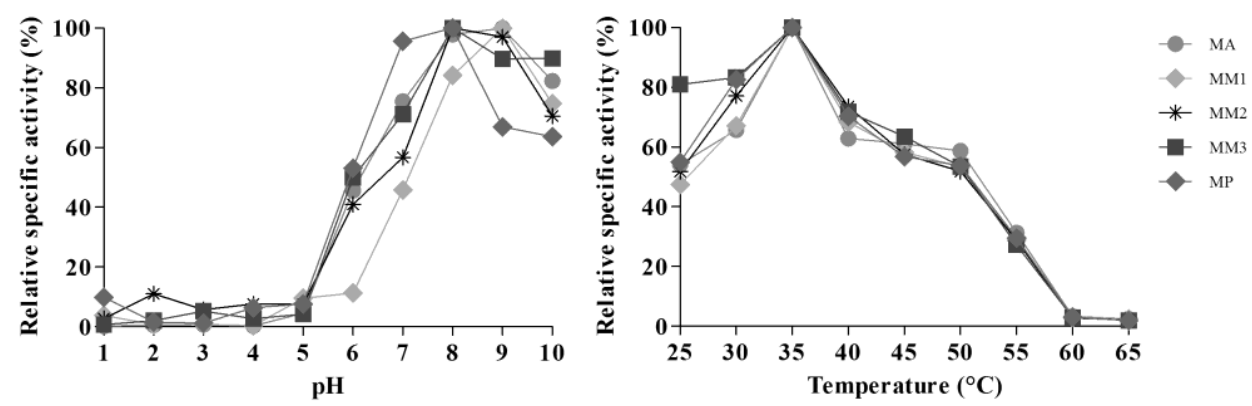

Fig. 3. Effect of $\mathrm{pH}$ (left) and temperature (right) on relative specific activity of $\alpha$-amylase along the digestive tract of Amblypharyngodon mola $(\mathrm{n}=10)$. Enzyme activity is expressed as relative specific activity $(\mathrm{RSA}) . \mathrm{RSA} \%=\left(\mathrm{Z}_{\mathrm{i}} / \mathrm{Z}_{\max }\right) \times 100\left[\mathrm{Z}_{\mathrm{i}}=\right.$ enzyme activity at specific $\mathrm{pH} ; \mathrm{Z}_{\max }=$ maximal enzyme activity at optimum $\mathrm{pH}]$.

Generally, amylase activity peaks at natural or alkaline $\mathrm{pH}$ (with a wide range of 7 to 9 ) in the fish intestine $[27,39,42]$. Some authors also reported that in some fish the optimum $\mathrm{pH}$ 
for amylase activity was slightly acidic from 4.5 to $6.7[40,43,44]$. The optimum temperature for the amylase activity was $35^{\circ} \mathrm{C}$ (Fig. 3). It was known that temperature ranging from $30^{\circ}$ to around $55^{\circ} \mathrm{C}$ favors amylase activity in wild fish $[27,35,39,41]$.

The studies of proteases mean the study of pepsin, trypsin, chymotrypsin, aminopeptidase, carboxypeptidase that act as a battery of enzymes $[45,46]$. The first two regions of the gut of $A$. mola (i.e. MA and MM1) were found to be the maximum proteolytically active (Fig. 2) and it fell further beyond MM2. This pattern was more or less similar to an herbivore fish Sarotherodon mossambicus where the proteases activity was high at the anterior and decreased towards the remaining region of the gut [47]. Proteases activity was highest at $\mathrm{pH} 7$ in the MM3 region of the intestine whereas in the other regions it was 8 (Fig. 4). The optimum $\mathrm{pH}$ for alkaline proteases was 8 in MA, MM1, MM2 except for MM3 where it was 7. So, the alkaline nature of gut favours protease digestion in A. mola. These findings were congruent with other studies where the optimum activity of proteases was reported close to $\mathrm{pH} 8$ to $10[48,49]$.
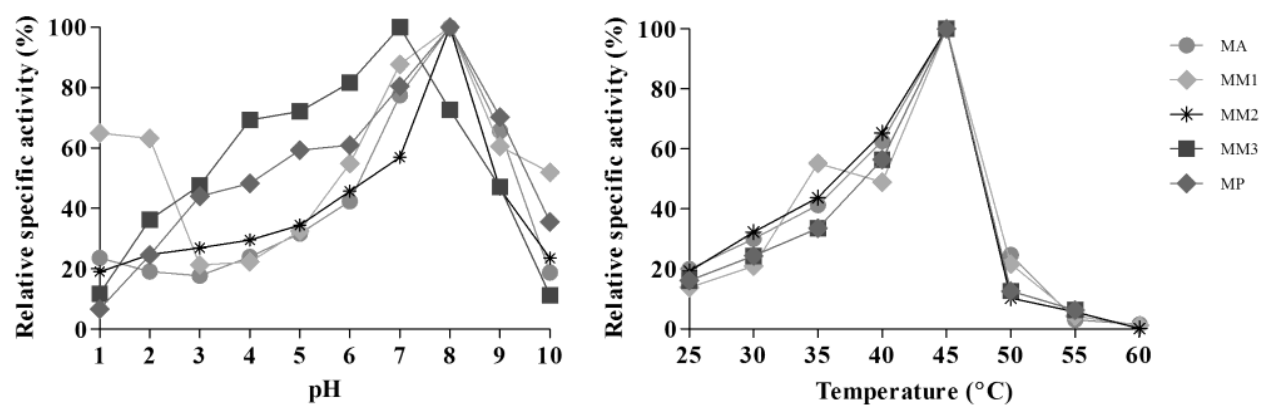

Fig. 4. Effect of $\mathrm{pH}$ (left) and temperature (right) on relative specific activity of proteases along the digestive tract of Amblypharyngodon mola $(\mathrm{n}=10)$. Enzyme activity is expressed as relative specific activity $(\mathrm{RSA}) . \mathrm{RSA} \%=\left(\mathrm{Z}_{\mathrm{i}} / \mathrm{Z}_{\max }\right) \times 100\left[\mathrm{Z}_{\mathrm{i}}=\right.$ enzyme activity at specific $\mathrm{pH} ; \mathrm{Z}_{\max }=$ maximal enzyme activity at optimum $\mathrm{pH}]$.

The MM1 region showed some degree of acid proteases activity at $\mathrm{pH} 1-2$, which was very unusual for a stomachless fish and may be possible due to some exogenous enzyme sources. Concerning temperature, in the current study, the maximum activity of proteases was found to be at $45{ }^{\circ} \mathrm{C}$ (Fig. 4). Earlier studies showed the activity of proteases was optimum in a range of $35-40{ }^{\circ} \mathrm{C}[43,48]$. However, some other classical studies reported a slightly higher optimum temperature of proteases activity ranging from 50 to $55{ }^{\circ} \mathrm{C}$ $[41,47,50]$.

Lipase is a very important digestive enzyme and responsible for the hydrolysis of ester bonds within the triacylglycerol at the hydrophilic-hydrophobic boundary [51,52]. The first three regions of the gut viz. MA, MM1, MM2 showed significantly higher activity of lipase compared to MM3 and MP (Fig. 2). The opening of the gall-bladder along with the hepatopancreas may be associated with the higher activity of lipase in the 
anterior region. Such an outcome was consistent with another stomachless fish Hyporhamphus regularisar delio [30]. The optimum pH for lipase was 8 (Fig. 5).
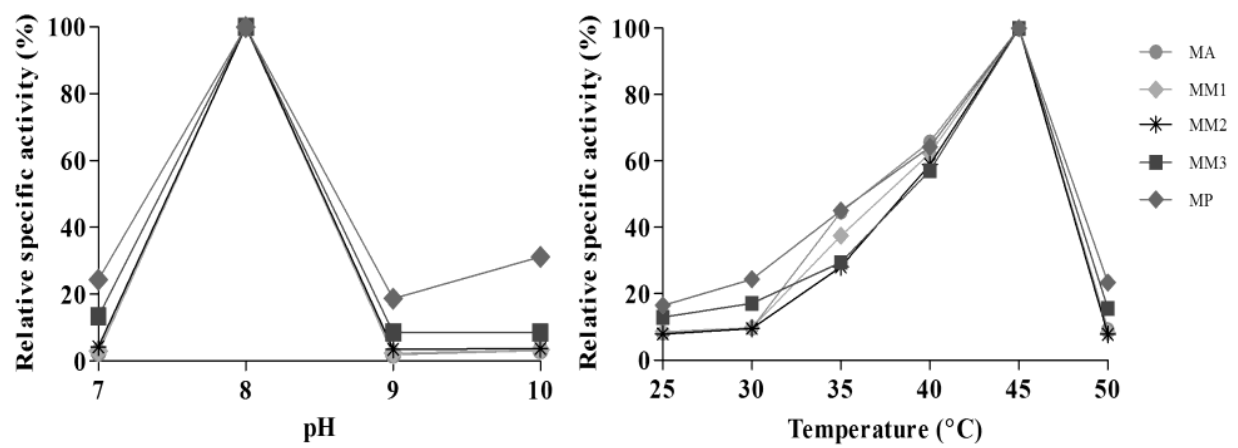

Fig. 5. Effect of $\mathrm{pH}$ (left) and temperature (right) on relative specific activity of lipase along the digestive tract of Amblypharyngodon mola $(\mathrm{n}=10)$. Enzyme activity is expressed as relative specific activity $(\mathrm{RSA}) . \mathrm{RSA} \%=\left(\mathrm{Z}_{\mathrm{i}} / \mathrm{Z}_{\max }\right) \times 100\left[\mathrm{Z}_{\mathrm{i}}=\right.$ enzyme activity at specific $\mathrm{pH} ; \mathrm{Z}_{\max }=$ maximal enzyme activity at optimum $\mathrm{pH}]$.

Different studies reported the optimum $\mathrm{pH}$ for lipase within alkaline range i.e. 8 to 9 [23, 32,51]. On the other hand, Fu et al. [53] recorded neutral or very close to neutral $\mathrm{pH}$ as optimum for lipase activity. In the present case, the optimum $\mathrm{pH}$ for lipase was found to be 8.0 (Fig. 5). The optimum temperature for lipase activity was $45^{\circ} \mathrm{C}$ in the studied fish (Fig. 5) similar to that of the Pacific bluefin tuna [27]. There are different optimum temperature reported for lipase activity in fish such as $35^{\circ} \mathrm{C}$ [28], $40{ }^{\circ} \mathrm{C}$ and $50{ }^{\circ} \mathrm{C}$ [39].

The physiological processes in fish are correspondent with the environmental temperature since the seasonal variation of temperature is one of the main extrinsic factors, which can influence the metabolic rate of aquatic organisms [54]. Digestive enzymes reach maximum activity at higher temperatures than those at which they currently act to allow for thermal adaptations [27]. For surface or bottom water levels, the optimum activity of enzymes at different temperatures may be an adaptation.

\subsection{Interaction of $\mathrm{pH}$, temperature and gut regions}

The influence of $\mathrm{pH}$ (Table 1) in the exposition of enzymes appeared as highly significant $(p<0.05)$. On the contrary, for proteases (both acidic and alkaline) and amylase (alkaline), the influence of gut regions on the digestive system was insignificant. But the influence of gut regions on the activity of acidic amylase and lipase showed prominence $(p<0.05)$. 
Table. 1. Results of two-way ANOVA analyses testing the influence of different gut regions, $\mathrm{pH}$ and their interactions on the activity of five different types of digestive enzymes.

\begin{tabular}{|c|c|c|c|}
\hline Dependent variable & Source & Degree of freedom & $\overline{p \text {-value }}$ \\
\hline \multirow{3}{*}{ Acidic Proteases } & Gut region & 4 & 0.193 \\
\hline & $\mathrm{pH}$ & 5 & 0 \\
\hline & Gut region $\mathrm{x} \mathrm{pH}$ & 20 & 0.999 \\
\hline \multirow{3}{*}{ Alkaline Proteases } & Gut region & 4 & 0.083 \\
\hline & $\mathrm{pH}$ & 5 & 0 \\
\hline & Gut region $\mathrm{x} \mathrm{pH}$ & 20 & 0.999 \\
\hline \multirow{3}{*}{ Acidic Amylase } & Gut region & 4 & 0 \\
\hline & $\mathrm{pH}$ & 5 & 0 \\
\hline & Gut region $\mathrm{x} \mathrm{pH}$ & 20 & 0.327 \\
\hline \multirow{3}{*}{ Alkaline Amylase } & Gut region & 4 & 0.052 \\
\hline & $\mathrm{pH}$ & 5 & 0 \\
\hline & Gut region $\mathrm{x} \mathrm{pH}$ & 20 & 0.372 \\
\hline \multirow{3}{*}{ Lipase } & Gut region & 4 & 0.058 \\
\hline & $\mathrm{pH}$ & 3 & 0 \\
\hline & Gut region $\mathrm{x} \mathrm{pH}$ & 12 & 0.993 \\
\hline
\end{tabular}

Table. 2. Results of two-way ANOVA analyses testing the influence of different gut regions, temperatures and their interactions on the activity of three different types of digestive enzymes.

\begin{tabular}{llll}
\hline Dependent variable & Source & Degree of freedom & p-value \\
\hline \multirow{3}{*}{ Proteases } & Gut region & 4 & 0 \\
& Temperature & 5 & 0.013 \\
& Gut region x Temperature & 20 & 0.997 \\
\hline \multirow{3}{*}{ Amylase } & Gut region & 4 & 0 \\
& Temperature & 5 & 0 \\
& Gut region x Temperature & 20 & 0.999 \\
\hline \multirow{2}{*}{ Lipase } & Gut region & 4 & 0.059 \\
& Temperature & 5 & 0 \\
& Gut region x Temperature & 20 & 0.999 \\
\hline
\end{tabular}

In the second Table (Table 2) too, the influence of gut regions on amylase and proteases were significant $(p<0.05)$ while it fails to be significant in lipase. In contrast to the influences of gut regions, the temperature had a strong significant effect on amylase and lipase but a very weak effect on proteases. The temperature has already been shown as an independent factor to influence amylase activity [54]. Gelman et al. [55] highlighted that enzyme adaptation to temperature is genetically determined and iso-enzyme may catalyze the same substrate with different maxima at different temperatures. A similar explanation may be forwarded for $\mathrm{pH}$ also. This is the reason why the interaction between two explanatory variables viz. gut region and $\mathrm{pH}$ or gut region and temperature for each type of enzymes portray as insignificant $(p<0.05)$ which clarifies the nature of independence of effect of each explanatory variable with respect to other in the study of the response. Apart from $\mathrm{pH}$ and temperature, different regions of the gut can significantly affect the 
activity of a particular digestive enzyme. Because, along the gut, the distribution of enzyme producing cells or the microenvironment for the digestive activity was not similar, and these attributes were strictly associated with the lumen of the gut only.

\subsection{Clustering of gut regions}

In case of temperature as a variable (Fig. 6), both Single linkage and Ward's method direct towards partitioning the whole gut regions in terms of three clusters viz. $\mathrm{C}_{1}$ : (MM1, MA), $C_{2}$ : (MM2), $C_{3}$ : (MM3, MP). In three cluster-partitioning the region MM2 ascertains its borderline character which might be sorted out if it was merged with (MM1, MA), hence forming $\mathrm{C}_{1}$ : (MM1, MA, MM2) and $\mathrm{C}_{2}$ : (MP, MM3).
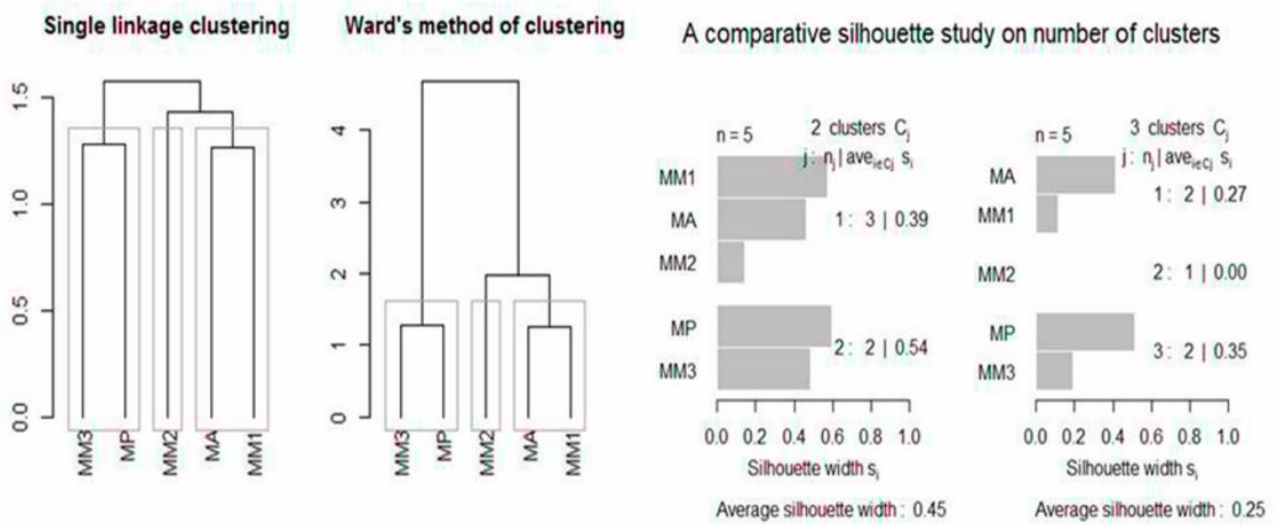

Fig. 6. Clustering of Gut regions in terms of enzyme secretion taking temperature as variable. Both Single linkage clustering and Ward's methods are shown. The comparative silhouette plots were also shown to describe the best numbers of clusters.

This merging would enhance within cluster silhouette width strengthening within cluster bond. But two cluster partitions are too trivial to deal with, so it is better to stick to three cluster partitioning. Similarly, in case of $\mathrm{pH}$ as a variable (Fig. 7.), both Single linkage and Ward's method uncover the same partitioning of gut regions viz. $\mathrm{C}_{1}: \mathrm{MM} 2, \mathrm{C}_{2}$ : (MA, MM1) and $\mathrm{C}_{3}$ : (MM3, MP). Moreover, the following silhouette analysis projects the average silhouette width as 0.54 which strongly validates the separation distance between the three resulting clusters.

\subsection{Probable enzyme niche}

The five regions of the tract discussed in our study are more or less different in terms of acting as a zone for the studied digestive enzyme. But, there lies a strong possibility for two or more gut regions to exhibit optimum enzyme activity in a similar manner. The region-wise activity of enzymes based on $\mathrm{pH}$ and temperature showed gut regions with similar enzyme activity and such homogeneous regions were termed as 'enzyme niche'. 
To check such 'enzyme niche' across the different gut regions of A. mola, the clustering technique was performed on the selected scaled variables. In the case of $\mathrm{pH}$ based clustering, all gut regions revealed three clusters in terms of the activity of all enzymes studied. Subsequently, similarity patterns of these gut regions with respect to the activity of the same enzymes with the range of temperature also exhibited three clusters. In both cases, the first enzyme niche comprises of MM1 and MA, whereas the second comprises of MM3 and MP and the third one was MM2. On comparison of silhouette analysis, the $\mathrm{pH}$ based clustering gave more strong niche formation in terms of gut functioning. In an agastric situation and loss of pyloric caeca, having a long intestine is an adaptive feeding in fish [56]. The existence of 'enzyme niche' as in the case of A. mola may be another feature to compensate agastric situation or mobilization of digestive functions.

Single linkage clustering

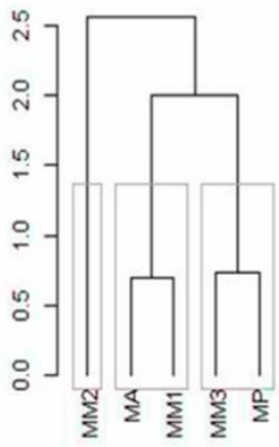

Ward's method of clustering

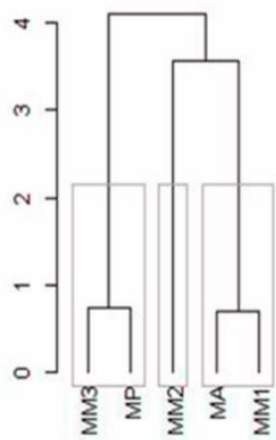

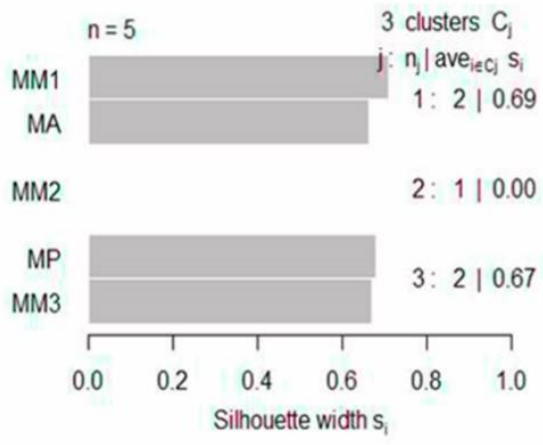

Average silhouette width: 0.54

Fig. 7. Clustering of Gut regions in terms of enzyme secretion taking $\mathrm{pH}$ as variable. Both Single linkage clustering and Ward's methods are shown. The comparative silhouette plots were also shown to describe the best numbers of clusters.

Therefore, in A. mola, clustering of gut regions in terms of enzyme activity from the perspective of $\mathrm{pH}$ delivers much explicit grouping than the same through the aid of temperature. The MM1 and MA, by their optimum proteolytic activity within a range of pH 8-9 may represent the anterior intestine of this fish. Similarly, MM3 and MP may represent the posterior intestine with low digestive activity. Interestingly, MM2 stands with moderate digestive nature between anterior and posterior intestine.

\section{Conclusion}

Digestive physiology in fishes is still incomplete with several gaps, and as such, our knowledge of digestion in stomachless fishes may not be conclusive. The present study provides an unexplored area of the feeding ecology of A. mola. It was evident that the activity of amylase in the gut is highest than the other two enzymes. All three types of enzymes had optimum $\mathrm{pH}$ value ranging from neutral to alkaline and the optimum 
temperatures were more or less within the range of $35-45^{\circ} \mathrm{C}$. The clusters further indicate an evolutionary direction where the agastric nature of progressively optimized digestive features of highly evolved fishes is reflected.

\section{Acknowledgment}

This work was supported by the Council of Science \& Industrial Research (CSIR), India. Authors also acknowledge the facility supported under the programmes DST-FIST and CAS, UGC in the Department of Zoology, Visva-Bharati, West Bengal, India. The support extended by DST-PARS program of the 'Siksha-Bhavana' is also acknowledged.

\section{Reference}

1. I. M. Pujante, M. Díaz-López, J. M. Mancera, and F. J. Moyano, Aquac. Res. 48, 367 (2017). https://doi.org/10.1111/are.13038

2. S. K. Saikia, Eur. J. Ecol. 2, 35 (2016). https://doi.org/10.1515/eje-2016-0004

3. D. P. German, M. H. Horn, and A. Gawlicka, Physiol. Biochem. Zool. 77, 789 (2004). https://doi.org/10.1086/422228

4. S. H. Thilsted, N. Roos, and N. Hassan, Naga, the ICLARM Quarterly 20, 82 (1997).

5. N. C. Roy, A. H. M. Kohinoor, M. A. Wahab, and S. H. Thilsted, Asian Fish. Sci. 15, 43 (2002).

6. C. Bijayalakshmi, N. Romen, and M. Shomorendra, Int. J. Curr. Res. 6, 4965 (2014).

7. R. S. Pishka, B. R. Swamy, and P. I. Devi, Ind. J. Fish. 38, 126 (1991).

8. A. Mamun, K. M. A. Tareq, and M. A. Azadi, Pak. J. Biol. Sci. 7, 584 (2004). https://doi.org/10.3923/pibs.2004.584.588

9. N. Roos, M. A. Wahab, M. A. R. Hossain, and S. H. Thilsted, Food Nutr. Bull. 28, S280 (2007). https://doi.org/10.1177/15648265070282S207

10. T. K. Sen, Records of the Zoological Survey of India (Zoological Survey of India, Calcutta, 1985).

11. S. Gupta and S. Banerjee, Zool. Ecol. 25, 54 (2015). https://doi.org/10.1080/21658005.2014.991513

12. F. Ahamed, Z. F. Ahmed, M. Y. Hossain, and J. Ohtomi, Egypt J. Aquat. Res. 43, 291 (2017). https://doi.org/10.1016/j.ejar.2017.11.002

13. F. Ahamed, M. N. Saha, Z. F. A. Rasel, and M. Y. Hossain, Int. J. Fish. Aquat. Stud. 5, 359 (2017).

14. F. Nawer, M. Hossain, M. Sarwar, O. Rahman, D. Khatun, M. F. Parvin, S. Jasmine, Z. F. Ahmed, F. Ahamed, and J. Ohtomi, Jordan J. Biol. Sci. 11, (2018).

15. S. Nandi and S. K. Saikia, Arch. Pol. Fisheries 23, 79 (2015). https://doi.org/10.1515/aopf-2015-0009

16. S. Nandi and S. K. Saikia, J. Fish Biol. 87, 215 (2015). https://doi.org/10.1111/jfb.12706

17. A. S. M. M. Hoque and M. R. Rahman, J. Agr. Rural. Dev. 6, 165 (2008). https://doi.org/10.3329/jard.v6i1.1674

18. M. Pal and B. K. Mahapatra, Int. J. Fish. Aquat. Stud. 4, 47 (2016).

19. M. F. Ahamed, N. S. Rasel, Z. M. G. Ara, F. Ahmed, and M. Y. Hossain, Int. J. Fish. Aquat. Stud. 5, 336 (2017).

20. Y. M. I. Hani, A. Marchand, C. Turies, E. Kerambrun, O. Palluel, A. Bado-Nilles, R. Beaudouin, J. M. Porcher, A. Geffard, and O. Dedourge-Geffard, Plos One 13, ID 0194932 (2018). https://doi.org/10.1371/iournal.pone.0194932

21. D. P. German and M. H. Horn, Mar. Biol. 148, 1123 (2006). https://doi.org/10.1007/s00227-005-0149-4

22. F. Zihler, Netherlands J. Zool. 32, 544 (1981). https://doi.org/10.1163/002829682X00210 
23. P. Bernfeld, Meth. Enzymol, ed. S. P. Colwick et al. (Academic Press, New York, 1955) vol. I, pp. 149-158.

24. E. S. Papoutsoglou and A. R. Lyndon, J. Fish. Biol. 69, 130 (2006).

https://doi.org/10.1111/j.1095-8649.2006.01082.x

25. H. E. Walter, Methods of Enzymatic Analysis, edited by H. J. Bergmeyer (Verlag Chemie, Weinham, 1984), pp. 270-277.

26. O. H. Lowry, N. J. Rosebrough, A. L. Farr, and R. J. Randall, J. Boil. Chem. 193, 265 (1951).

27. A. M. de La Parra, A. Rosas, J. P. Lazo, and M. T. Viana, Fish. Physiol. Biochem. 33, 223 (2007). https://doi.org/10.1007/s10695-007-9134-9

28. I. Kurtovic, S. N. Marshall, X. Zhao, and B. K. Simpson, Fish. Physiol. Biochem. 36, 1041 (2010). https://doi.org/10.1007/s10695-010-9382-y

29. M. M. Solovyev, E. N. Kashinskaya, G. I. Izvekova, and V. V. Glupov, J. Ichthyol. 55, 251 (2015). https://doi.org/10.1134/S0032945215010208

30. R. D. Day, D. P. German, and I. R. Tibbetts, Comp. Biochem. Physiol. B Biochem. Mol. Biol. 158, 23 (2011). https://doi.org/10.1016/j.cbpb.2010.09.010

31. D. A. Z. Abidin, M. Hashim, S. K. Das, S. M. Rahim, and A. G. Mazlan, AACL Bioflux 9, 695 (2016).

32. E. M. Toloza and J. M. Diamond, Am. J. Physiol. Gastro. Liver Physiol. 258, G770 (1990). https://doi.org/10.1152/ajpgi.1990.258.5.G770

33. A. H. Al-Hussaini, The Feeding Habits and the Morphology of the Alimentary Tract of Some Teleosts: Living in the Neighbourhood of the Marine Biological Station, Ghardaqa, Red Sea (Fouad I University Press, Cairo, Egypt, 1947).

34. D. L. Kramer and M. J. Bryant, Environ. Boil. Fishes 42, 129 (1995). https://doi.org/10.1007/BF00001991

35. F. B. Candiotto, A. C. V. Freitas-Júnior, R. C. A. Neri, R. S. Bezerra, R. V. Rodrigues, L. A. Sampaio, and M. B. Tesser, Braz J. Biol. 78, 281 (2018). https://doi.org/10.1590/1519$6984.06616 \mathrm{~N}$

36. W. Uys and T. Hecht, Aquaculture 63, 301 (1987). https://doi.org/10.1016/0044-8486(87)90080-9

37. L. M. Lundstedt, J. F. B. Melo, and G. Moraes, Comp. Biochem. Physiol. B 137331 (2004). https://doi.org/10.1016/j.cbpc.2003.12.003

38. A. Krogdahl, G. I. Hemre, and T. P. Mommsen, Aquac. Nutr. 11, 103 (2005). https://doi.org/10.1111/j.1365-2095.2004.00327.x

39. D. M. Xiong, C. X. Xie, H. J. Zhang, and H. P. Liu, J. Anim. Physiol. Anim. Nutr. 95, 56 (2011).

40. I. Fernandez, F. J. Moyano, M. Diaz, and T. Martinez, J. Exp. Mar. Biol. Ecol. 262, 1 (2001). https://doi.org/10.1016/S0022-0981(01)00228-3

41. F. J. Alarcón, T. F. Martinez, M. Díaz, and F. J. Moyano, Hydrobiologia 445, 199 (2001). https://doi.org/10.1023/A:1017521900442

42. C. Champasri, T. Champasri, J. Fish. Aqut. Sci. 12, 264 (2017). https://doi.org/10.3923/jfas.2017.264.272

43. U. Sabapathy and L. H. Teo, Comp. Biochem. Physiol. B Comp. Biochem. 109, 139 (1994). https://doi.org/10.1016/0305-0491(94)90150-3

44. R. Munilla-Moran and F. Saborido-Rey, Comp. Biochem. Physiol. B Biochem. Mol. Biol. 113, 827 (1996). https://doi.org/10.1016/0305-0491(95)02101-9

45. S. Klomklao, Songklanakarin, J. Sci. Techno. 30, 37 (2008).

46. S. Unajak, P. Meesawat, A. Paemanee, N. Areechon, A. Engkagul, U. Kovitvadhi, S. Kovitvadhi, K. Rungruangsak-Torrissen, and K Choowongkomon, Food Chem. 134, 1533 (2012). https://doi.org/10.1016/i.foodchem.2012.03.074

47. R. Hofer and F. Schiemer, Oecologia, 48, 342 (1981). https://doi.org/10.1007/BF00346492

48. E. Peña, C. Hernández, C. A. Álvarez-González, L. Ibarra-Castro, A. Puello-Cruz, and R. W. Hardy, Lat. Am. J. Aquat. Res. 43, 641(2015). 
49. N. Aissaoui, M. N. Marzouki, and F. Abidi, Int. J. Food Prop. 20, 2151 (2017). https://doi.org/10.1080/10942912.2017.1368550

50. F. J. Alarcón, M. Díaz, and F. J. Moyano, Cah. Options Mediterr. 22, 113 (1997).

51. J. Park, S. Y. Cho, and S. J. Choi, BMB reports 41, 254 (2008). https://doi.org/10.5483/BMBRep.2008.41.3.254

52. N. Prim, M. Sánchez, C. Ruiz, F. J. Pastor, and P. Diaz, J. Mol. Catal. B Enzym. 22,339 (2003). https://doi.org/10.1016/S1381-1177(03)00048-1

53. X. H. Fu, M. Sun, and S. C. Sun, J. Fish. Sci. China 12, 26 (2005).

54. Y. M. I. Hani, A. Marchand, C. Turies, E. Kerambrun, O. Palluel, A. Bado-Nilles, R. Beaudouin, J. M. Porcher, A. Geffard, and O. Dedourge-Geffard, PloS One 13, 0194932 (2018). https://doi.org/10.1371/journal.pone.0194932

55. A. Gelman, V. Kuz'mina, V. Drabkin, and L. Glatman, Temperature Adaptations of Fish Digestive Enzimes, Feed and Digestive Functions in Fishes, Edited by J. E. P. Cyrino, D. Bureau, and B. G. Kapoor, (Auburn University, USA Production Department, Oxford \& IBH Publishing Co. Pvt. Ltd, 2008), pp. 155-226.

56. K. Opuszynski and J. V. Shireman, Environ. Biol. Fishes 30, 387 (1991). https://doi.org/10.1007/BF02027982 